\title{
Spillovers from Europe into Morocco and Tunisia
}

\author{
Reinout De Bock, Daniel Florea, and \\ Joël Toujas-Bernaté
}




\title{
IMF Working Paper
}

Middle East and Central Asia Department

\section{Spillovers from Europe into Morocco and Tunisia ${ }^{1}$}

\section{Prepared by Reinout De Bock, Daniel Florea, and Joël Toujas-Bernaté}

Authorized for distribution by Joël Toujas-Bernaté

October 2010

\begin{abstract}

\section{This Working Paper should not be reported as representing the views of the IMF.} The views expressed in this Working Paper are those of the author(s) and do not necessarily represent those of the IMF or IMF policy. Working Papers describe research in progress by the author(s) and are published to elicit comments and to further debate.
\end{abstract}

This paper examines the economic and financial linkages between Morocco and Tunisia and their European partners. Using structural vector autoregressions, we find that growth shocks in European partner countries generate significant responses on growth in Morocco and Tunisia. For Tunisia, exports and, to a much lesser extent, tourism appear to be the major transmission channels. In Morocco, exports, remittances and tourism play relatively equal roles. An analysis with sectoral data supports these results.

JEL Classification Numbers: C52; E32; F42; F43

Keywords: Morocco; Tunisia; Spillovers; Trade; Business cycles; Transmission channels

Author's E-Mail Address: rdebock@imf.org, daniel.florea@finances.gouv.qc.ca, jtoujasbernate@imf.org

\footnotetext{
${ }^{1}$ We thank participants of the 2010 CREMed Workshop on Economies of the Mediterranean and the EuroMediterranean Process at the Universitat Pompeu Fabra for helpful discussions. We also benefitted from comments from Patricia Alonso-Gamo, Ralph Chami, Mohammed Daïri, Juan Carlos Jaramillo and Sadok Rouai. All errors are the sole responsibility of the authors.
} 


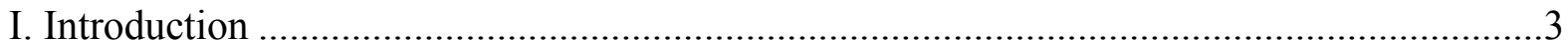

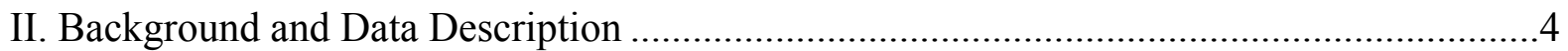

A. Economic Policy and Links with Partner Countries ........................................................... 4

B. Correlation of Growth Rates with European Partners...........................................................

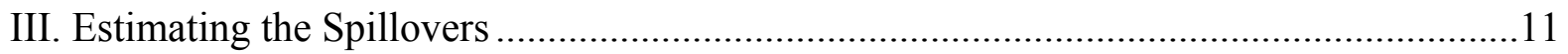

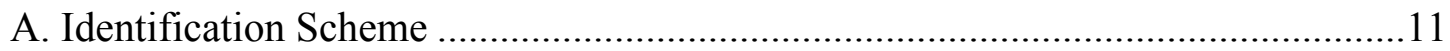

B. Responses to External Growth Shock ………………..........................................11

C. Alternative Identification of Shocks ……………….............................................13

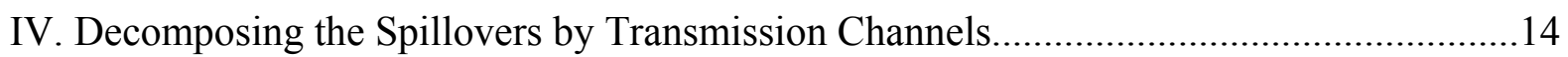

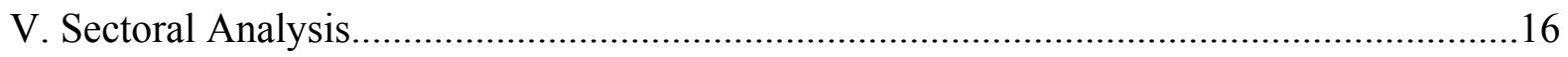

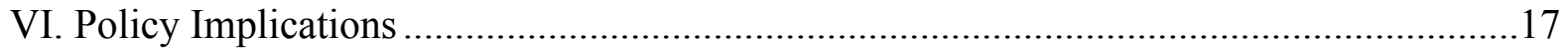

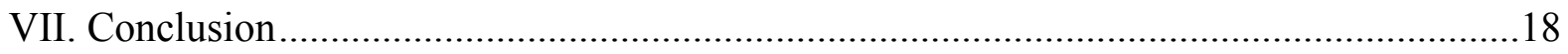

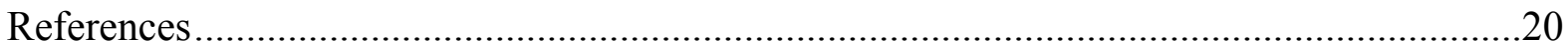

Boxes

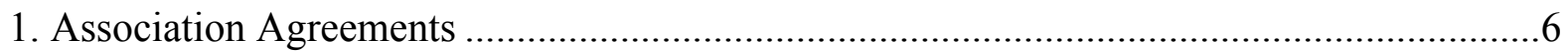

2. Some of the Remaining Restrictions on Foreign Currency transactions and

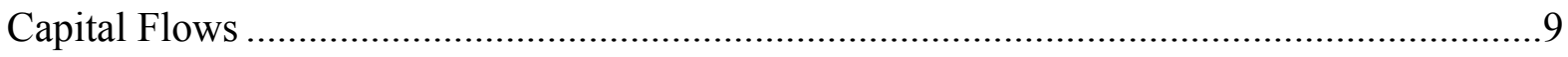

Figures

1. Total Imports and Exports (Millions of USD, 1990-2008) ………....................................

2. Shares of Exports, Tourism, and Remittances (Percent of GDP), 2008 ..............................5

3. EU Shares in Exports, Tourism, and Remittances (in Percent, average, 2005-08)...............7

4. FDI in Morocco and Tunisia, (Average 2005-08) .........................................................

5. Response of Domestic Growth to an External Growth Shock............................................12

6. Short-Run Versus Long-Run Restrictions .....................................................................14

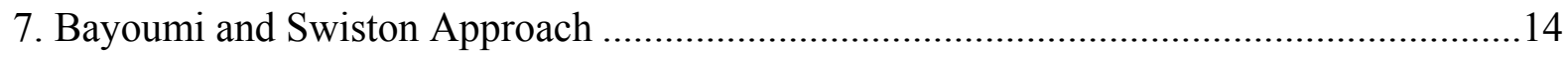

8. Cumulative Responses to Growth Innovation in Partner Composite ..................................15

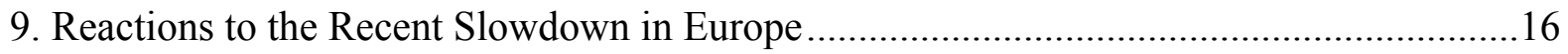

10. Cumulative Response of Sector Growth to an External Growth Shock .............................16

11. Euro Area—Real GDP and Real Imports Growth .......................................................17

12. EU and UMA Shares in Imports, Exports and Trade Balance ........................................18

Tables

1. Banks' External Debt Statistics (Percent of GDP), 2000-09 ……......................................

2. Volatility and Correlation Coefficients of Growth Rates, 2000Q1-2009Q4 .....................10

3. Forecast Error Variance Decompositions.......................................................................13

4. Morocco and Tunisia Shares in EU Imports ………...................................................18

Appendix

Trade Weigths from the Global Economic Environment (GEE)..........................................20 


\section{INTRODUCTION}

This paper examines the effect of growth shocks in European countries on economic activity in Morocco and Tunisia. ${ }^{2}$ Both Morocco and Tunisia have taken significant steps to open up their economies and signed association agreements with the European Union (EU) in the mid nineties. ${ }^{3}$ In the past decade, these countries have attracted sizable inflows of foreign direct investment (FDI), liberalized trade and lowered the entry barriers for foreign banks into domestic financial markets. Today, they rely on Europe for a large share of their external receipts (exports, tourism receipts, workers' remittances and FDI), and growth is likely to be significantly influenced by events in their main European partners. Although the global crisis in 2008-09 did not cause a recession in Morocco or Tunisia, the recession in the EU had a clear impact on their external receipts.

In the context of increasing globalization, there has been a renewed interest in examining business cycle synchronization and spillovers of economic activity across countries. Recent studies have developed an approach to identify common shocks and spillovers. In line with these studies, we use structural vector autoregressions (SVARs) models to measure the response of Tunisian and Moroccan growth to an innovation in the growth rate of key partner countries. While simple contemporaneous correlations suggest strong business cycle comovement, SVARs have the additional advantage that they capture dynamic patterns present in the data and allow for a structural interpretation of impulse responses. Following Bayoumi and Swiston (2009), we also use our baseline SVARs to gauge the contribution of different factors such as trade, revenues from tourism and remittances. A wide literature has suggested that these variables can be the source of important transmission channels of shocks across regions. ${ }^{4}$

We find that positive shocks to a growth composite of trade partners have significant expansionary hump-shaped effects on growth in Morocco and Tunisia. Our analysis suggests noticeable differences in the transmission channels of these shocks in the two countries. For Tunisia, exports, and to a much lesser extent tourism, appear to be the major channels. Exports are also important in Morocco, but an equally important role is played by remittances and tourism. Our results are consistent with the evolution of the different macroeconomic aggregates in the wake of the 2008 recession in Europe. Moreover, an analysis by sector supports these results. In particular, re-estimating the VARs with sectoral data shows that the export-oriented sectors are the ones with significant responses to external growth shocks in Tunisia. In contrast, service-related sectors appear to be the most sensitive to external growth shocks in Morocco.

\footnotetext{
2 There is a large literature examining linkages and sources of spillovers between countries. See, for example, Canova and Dellas (1993), Kose, Otrok, and Whiteman (2003), Baxter and Kouparitsas (2004), and Bayoumi and Swiston (2009). Toujas-Bernaté, Loko, and Simard (2009) investigate growth spillovers from Europe into Tunisia.

${ }^{3}$ In 2009 MSCI Barra classified Morocco as an emerging market and Tunisia as a frontier market.

${ }^{4}$ See, among others, Imbs (2004), Arezki and all (2009), and Gapen (2009).
} 
The paper is organized as follows. The first subsection of section II provides background information on the economic policy of both countries in the past decades and the role of the European Union as an export destination, and a source of tourism revenues, remittances and FDI. The second subsection describes the GDP data and looks at contemporaneous correlations between the different growth rates. In section III we estimate the spillovers using a SVAR analysis and we check the robustness of the results examining an alternative identification scheme for the structural shock. Section IV analyzes the role of different transmission channels, while in Section V we are redoing the SVAR analysis with sectoral data. Finally, Section VI identifies a number of policy issues in light of these results, while taking into account growth forecasts for Europe. Section VII concludes.

\section{BACKGROUND AND DATA DESCRIPTION}

\section{A. Economic Policy and Links with Partner Countries}

In the past decades Morocco and Tunisia have taken significant steps in opening up their economies. Aside from a similar geographical position, both countries are small open economies with important historical and cultural ties with Europe. Tunisia signed an association agreement with the European Union in 1995 and implemented it in 1998. Morocco signed an association agreement in 1996, which entered into force in 2000 (Box 1). Both agreements are part of a broader approach of the European Union (EU) towards widening its relations with neighboring countries from the south of the Mediterranean and aiming at the long-term objective of building a Euro-Mediterranean economic area. The implementation of the association agreements produced important changes for the two economies. Since then trade flows increased exponentially (Figure 1). ${ }^{5}$ Although other factors, such as globalization and structural reforms adopted in both Morocco and Tunisia after 2000, are also at play, the impact of the association agreements on both countries appears to be significant.

\footnotetext{
${ }^{5}$ Unless otherwise specified, by exports, we understand exports of goods.
} 
Figure 1. Total Imports and Exports

(Millions of USD, 1990-2008)
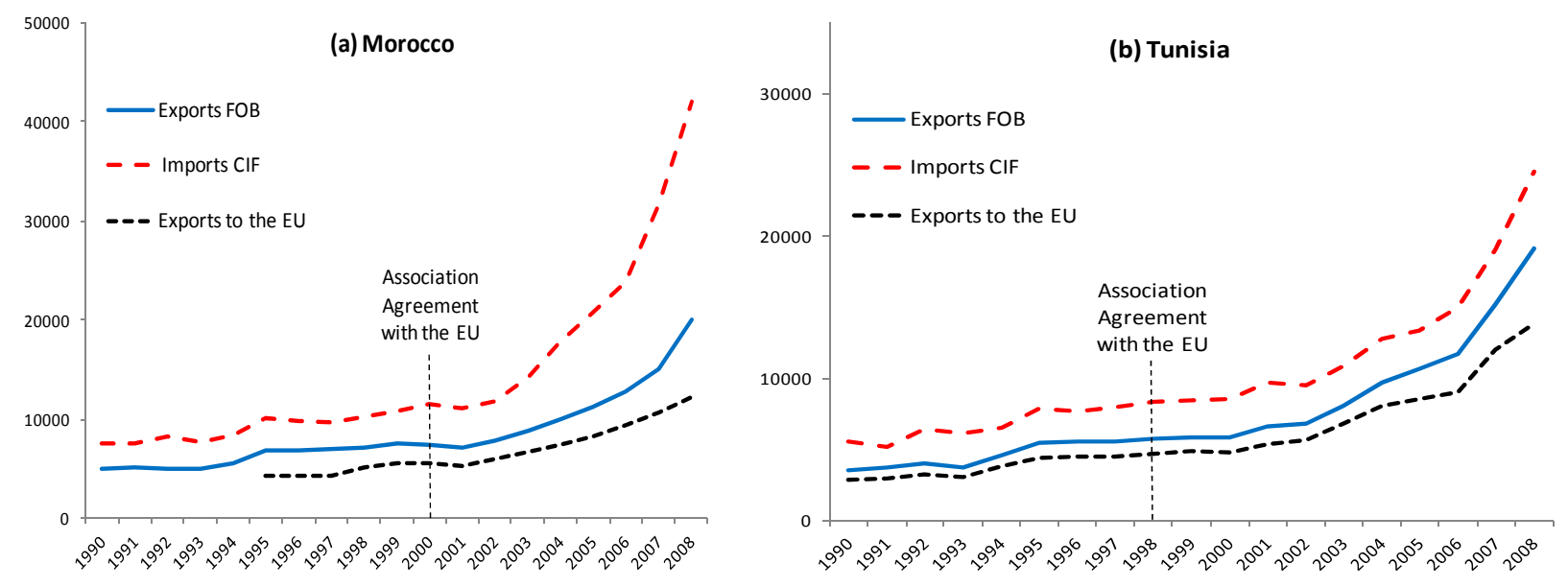

Source: Country's authorities; and IMF staff estimates.

Exports, tourism and remittances are sizable in both Morocco and Tunisia, although their importance varies between the two countries (Figure 2). Relative to GDP, exports are substantially higher in Tunisia than in Morocco. In contrast, tourism and remittances appear to be more important in Morocco. For example, the ratio of remittances to GDP in Morocco is double the ratio in Tunisia.

Figure 2. Shares of Exports, Tourism, and Remittances, 2008

(In percent of GDP)
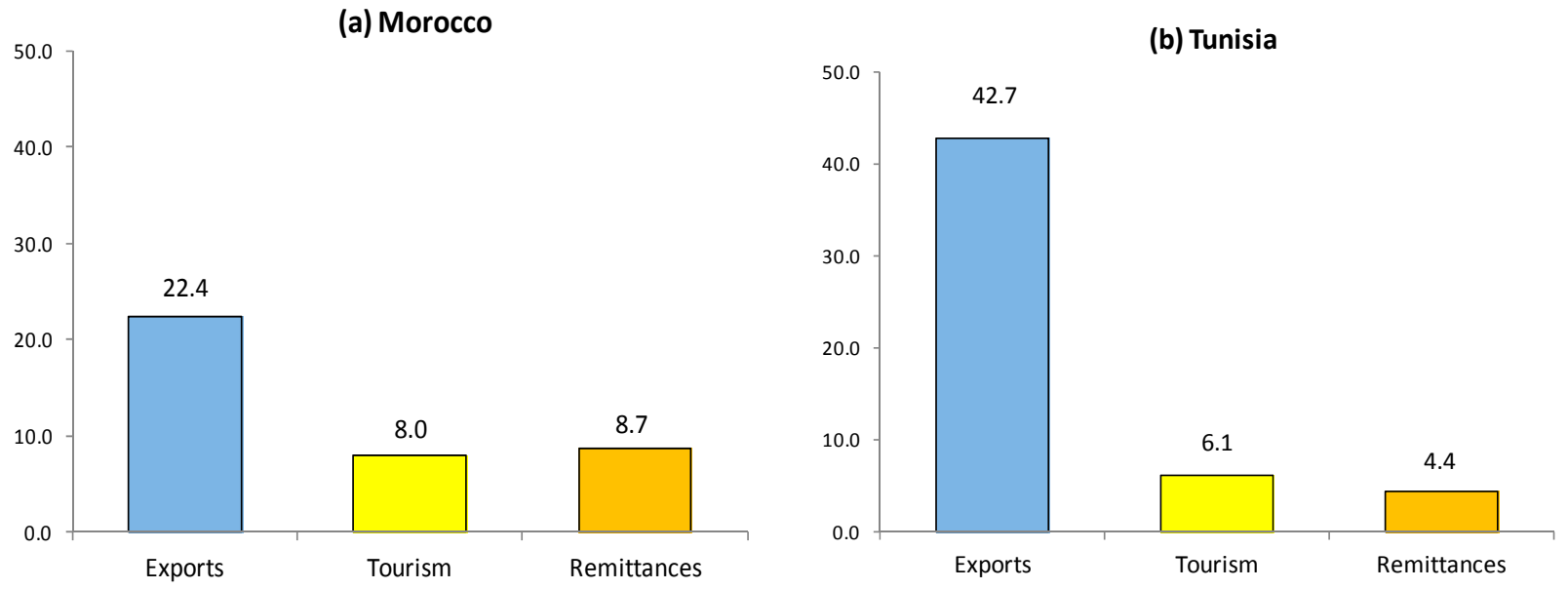

Source: Country's authorities; and IMF staff estimates. 


\section{Box 1. Association Agreements}

\section{(a) The Association Agreement Between Morocco and the European Union}

The EU-Morocco Association Agreement was signed in February 1996, and entered into force in March 2000, following its ratification by the Parliaments of the EU Member States, the European Parliament and the Moroccan Parliament.

The Agreement aims at gradually creating a free trade area for industrial products. The EU committed to give instantaneously free access to products originating from Morocco, while Morocco implemented a gradual dismantling of its trade tariffs, according to a specific schedule. Furthermore, progressive and reciprocal liberalization of trade for a number of agricultural products started in January 2004. The Agreement also includes provisions on freedom of establishment and the liberalization of services, and free movement of capital and competition rules. From a political perspective, respect for human rights and democratic principles constitutes an essential element of the Agreement. The text equally refers to regular political dialogue at senior official level on peace, security, and regional co-operation. Another important chapter of the Association Agreement refers to the question of migration and social affairs. Following the entry into force of the agreement, a constant dialogue at Ministerial and expert level on migration and related areas has been held.

In 2008, Morocco obtained "advanced status" relations, a move which provides greater access to the EU's internal market and which places Morocco a notch above the members of the "neighborhood policy." Under the terms of the advanced status, Morocco will also participate in European civil and military crisis management operations, as well as in a number of European agencies, such as Europol, the European Air Security Agency, and the European Monitoring Center for Drugs and Drug Addiction.

\section{(b) The Association Agreement between Tunisia and the European Union}

Tunisia signed a bilateral Association Agreement with the EU in July 1995 and implemented it in March 1998. An amendment covering agricultural products was implemented on January 1, 2001.

The Agreement has three main features. First, it liberalized trade relations through the immediate abolition of quantitative restrictions and a gradual reduction of trade barriers which culminated in free trade for industrial goods in 2008. Trade liberalization pertaining to agriculture products and negotiations to liberalize the trade of services are still ongoing. Second, it contributed to harmonizing Tunisia's regulatory framework with the one in place in the EU, particularly for trade-related policies, norms and standards including in transport and telecommunications, accounting and financial services, and statistics. Third, it provided support for sectors facing more difficulties to adjust to the trade liberalization (the "mise à niveau" program) and enhanced cooperation, notably in the development of infrastructure. The European Neighborhood Policy builds on the Association Agreement by focusing the bilateral cooperation between Tunisia and the EU on more targeted programs. It was developed in 2004 and concluded with Tunisia in 2005. It provides increased financial support and favors enhanced regional cooperation for trade integration and the development of infrastructure (particularly for energy, transport, and information technology); improvements in the business climate (particularly through streamlined taxation and customs procedures, and strengthened intellectual and property rights); and a consolidated macroeconomic framework.

The EU is the main destination of exports for both Morocco and Tunisia (Figure 3). The EU's average share in Moroccan exports for the period 2005-08 was 70 percent. For Tunisia this share is slightly higher, at 77 percent. The EU plays an even more prominent role when it comes to 
tourism and remittances. The average shares for tourism revenues and remittances originating from the EU during the same period (2005-08) are between 80 percent and 90 percent. Moreover, these shares appear to be relatively stable over time.

Figure 3. EU Shares in Exports, Tourism and Remittances

(In percent, average 2005-08)

(a) Morocco

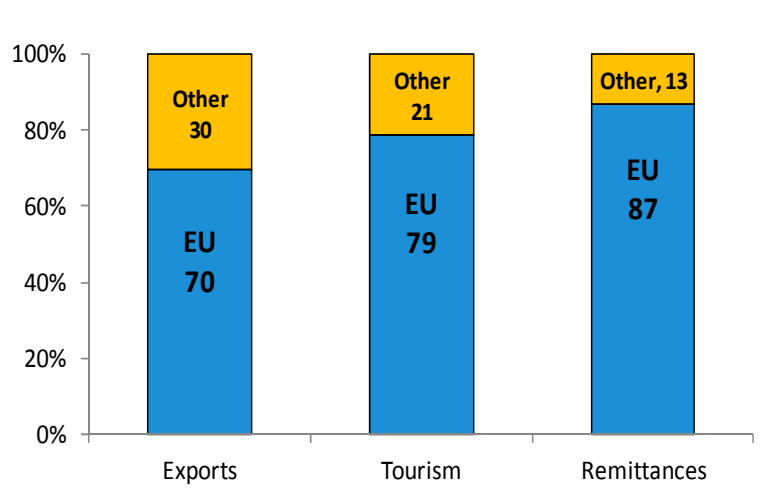

(b) Tunisia

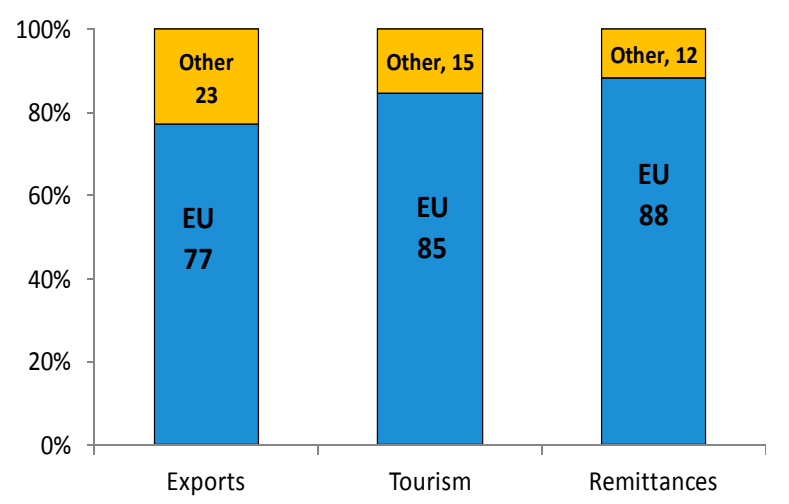

Source: Country's authorities; and IMF staff estimates

Other channels might also be explored to examine the interrelation between the European Union and Morocco and Tunisia's economies, such as imports, foreign direct investment (FDI) flows, as well as financial linkages. Regarding FDI, although these flows are generally volatile, Figure 4 suggests that they represent a potentially important transmission channel between the EU and the Moroccan and Tunisian economies. We consider however that the effect of FDI is mainly structural and manifests itself in the medium to long term. As such, it is less suited for an analysis centered on business cycles correlations.

Figure 4. FDI in Morocco and Tunisia (Average 2005-08)

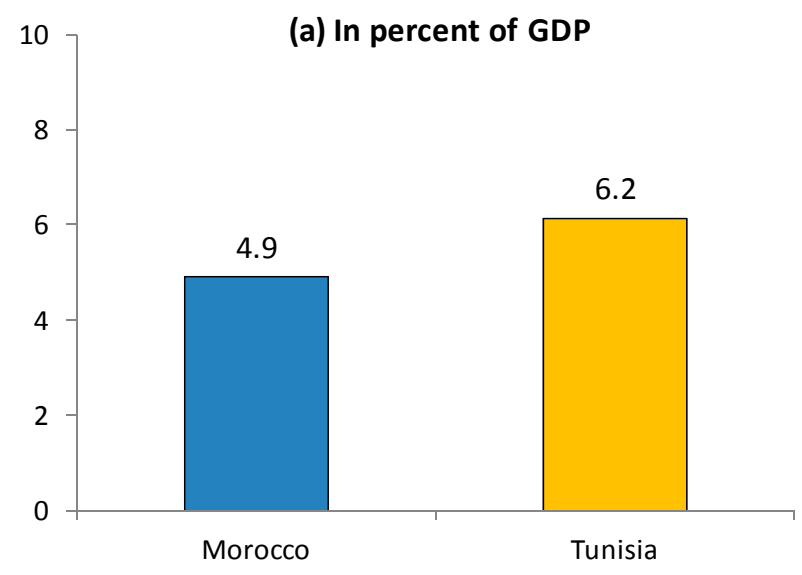

(b) EU share in total FDI

Source: Country's authorities; and IMF staff estimates.

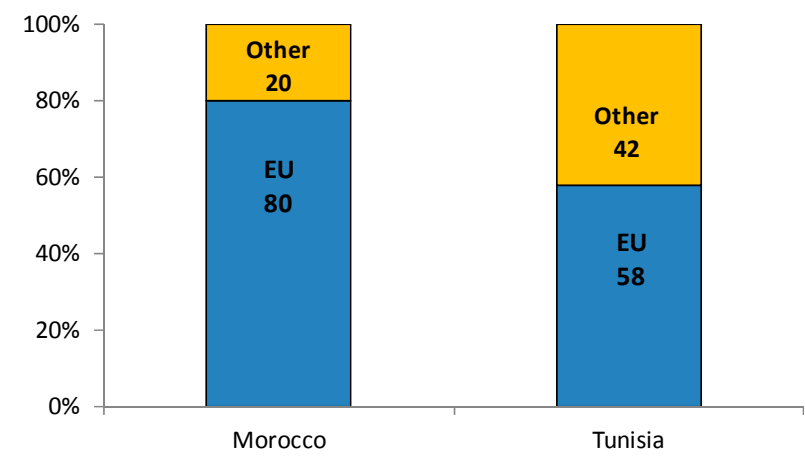


Turning to the transmission of shocks through financial channels, the Moroccan and Tunisian banking systems have limited links with international markets. Banking activities are funded in large part with domestic deposits (75 percent of banks' resources in Morocco and 80 percent in Tunisia) and cross-border financing is small. In 2009 short-term foreign liabilities of Moroccan and Tunisian banks to external counterparts reported to the Bank for International Settlements (BIS) represented only 3.3 and 1.2 percent of their respective GDP (Table 1). Moreover, in both countries the capital account is only partially open. Several restrictions apply to transactions in foreign currency, foreign borrowing and foreign investment by domestic firms (Box 2).

Table 1. Banks' External Debt Statistics, 2000-09 (In percent of GDP)

\begin{tabular}{lcccccccccc}
\hline & 2000 & 2001 & 2002 & 2003 & 2004 & 2005 & 2006 & 2007 & 2008 & 2009 \\
\hline Morocco & & & & & & & & & & \\
Liabilities to BIS banks & 17.7 & 16.1 & 15.3 & 11.9 & 10.8 & 8.9 & 7.5 & 7.9 & 8.4 & 9.8 \\
S-T Liabilities to BIS banks & 4.8 & 5.3 & 4.7 & 2.7 & 2.6 & 2.6 & 3.2 & 2.9 & 2.1 & 3.3 \\
Tunisia & & & & & & & & & & \\
Liabilities to BIS banks & 7.7 & 7.0 & 7.2 & 7.3 & 7.5 & 5.6 & 6.1 & 5.7 & 5.2 & 4.8 \\
S-T liabilities to BIS banks & 2.6 & 2.0 & 1.7 & 1.7 & 1.7 & 1.5 & 2.0 & 1.4 & 1.2 & 1.2 \\
\hline
\end{tabular}

Source: Bank for International Settlements, Country authorities; and IMF staff calculations.

Foreign banks have non-negligible presences in the two countries' banking systems. Majorityowned foreign banks accounted for 21.4 percent of total banking assets in Morocco (2008) and for 29.4 percent in Tunisia (2009). This presence might play a role in terms of increased competition, improved banking practices and diversification of funding sources but, as in the case of imports and FDIs, these effects are more likely to appear in the long run. Nevertheless, the impact of the opening of the domestic market to foreign banks in Morocco and Tunisia is a subject that deserves a multiple-angled analysis which goes beyond the purpose of our paper. 


\section{Box 2. Some of the Remaining Restrictions on Foreign Currency Transactions and Capital flows}

\section{(a) Morocco}

Moroccan exporters of goods and services may open foreign exchange accounts domestically and deposit up to 50 percent of the repatriated foreign exchange receipts from exports. Foreign residents and corporations may open foreign exchange accounts without limitations.

Commercial banks may borrow abroad only to finance foreign trade or investment operations on behalf of customers or as part of the introduction of the forward cover for customers' foreign exchange swaps, with maturities equal to the duration of the hedging operations offered.

There are no controls on inward direct investment. Outward direct investments are subject to approval, but resident corporations in operation for more than three years benefit from certain facilities. Resident foreign nationals are free to invest abroad, provided the operations are financed from their own funds abroad or from their holdings denominated in convertible dirham or foreign exchange.

A number of measures were taken during 2009 to further liberalize the capital account.

\section{(b) Tunisia}

Professional accounts in foreign currency may be opened by resident individuals, Tunisian legal entity and foreign legal entity in Tunisia with foreign currency assets in connection with its activities. Authorization by the Central Bank of Tunisia (BCT) is required for residents to open accounts abroad. Export proceeds must be repatriated within a time limit from the payment due date. However, resident exporters may retain up to 100 percent of their foreign exchange export proceeds.

The acquisition of assets (capital and money market instruments) abroad by residents is subject to authorization. Residents are also required to repatriate all income from investment abroad, as well as all proceeds from the divestiture or liquidation of such investments.

Stocks in existing companies in Tunisia may be acquired freely with foreign exchange transferred from abroad by foreign nonresidents. However, the acquisition by foreigners of shares with voting rights is subject to the approval of the High Investment Commission. Nonresidents may also sell freely shares of companies established in Tunisia. They may also transfer freely net real proceeds from the sale of shares that were purchased with foreign exchange transferred from abroad.

Source: International Monetary Fund, 2009, Annual Report on Exchange Arrangements and Exchange Restrictions (AREAER).

\section{B. Correlation of Growth Rates with European Partners}

Growth rates of Morocco and Tunisia, on one hand, and their key European partners, on the other hand, appear strongly positively correlated in the last decade. In our econometric analysis,

we use real nonagricultural year-on-year growth rates of GDP series for Morocco $g_{t}^{M O R, N A}$ and 
Tunisia $g_{t}^{T U N, N A}{ }^{6}$ These series are seasonally adjusted and available on a quarterly basis. For the EU, a country-specific composite GDP growth rate $g_{t}^{E U}(\bullet)$ is calculated as a weighted average of growth rates of the main EU partners based on the weights these countries take in Morocco's and Tunisia's exports of goods respectively. The country weights are constructed by the IMF for the Global Economic Environment (GEE). The appendix contains the formula for $g_{t}^{E U}(\bullet)$ and tables with the GEE weights used for Morocco and Tunisia.

Table 2. Volatility and Correlation Coefficients of Growth Rates, 2000Q1-2009Q4

\begin{tabular}{|c|c|c|c|c|c|}
\hline & $g_{t}^{M O R, N A}$ & $g_{t}^{E U}(M O R)$ & $g_{t}^{T U N, N A}$ & $g_{t}^{E U}(T U N)$ & $g_{t}(\mathrm{Oil})$ \\
\hline$g_{t}^{M O R, N A}$ & 1.69 & & & & \\
\hline \multirow[t]{2}{*}{$g_{t}^{E U}(M O R)$} & 0.46 & 2.08 & & & \\
\hline & (3.21) & & & & \\
\hline$g_{t}^{T U N, N A}$ & \multicolumn{5}{|c|}{1.59} \\
\hline$g_{t}^{E U}(T U N)$ & & & 0.63 & 2.05 & \multirow{4}{*}{14.60} \\
\hline \multirow{3}{*}{$g_{t}(\mathrm{Oil})$} & & & (5.06) & & \\
\hline & 0.16 & & -0.07 & & \\
\hline & $(0.98)$ & & $(-0.43)$ & & \\
\hline
\end{tabular}

Source: IMF staff estimates.

Standard deviations are on the diagonal and correlations off-diagonal. Between brackets are the T-stats for the null hypothesis that a single correlation coefficient is equal to zero. Oil is the spot petroleum price (average of Fateh, Brent and WTI) in US\$ scaled by US CPI.

Table 2 shows a strong positive correlation between the growth rates $g_{t}^{E U}(M O R)$ and $g_{t}^{M O R, N A}$ and $g_{t}^{E U}(T U N)$ with $g_{t}^{T U N, N A} .^{7}$ This correlation is 46 percent for Morocco and 63 percent for Tunisia. Statistical tests reject the hypothesis that these correlations are equal to zero. The table also shows that there is no strong correlation between growth in real petroleum spot prices, $g_{t}(\mathrm{Oil})$,

\footnotetext{
${ }^{6}$ We exclude agricultural output from GDP as this component remains largely dependent on climatic factors in both countries. In what follows, unless otherwise specified, we understand nonagricultural GDP when referring to Morocco and Tunisia's GDP.

${ }^{7}$ We found similar numbers when calculating the correlation of Moroccan and Tunisian growth rates with eurozone GDP reported by Eurostat.
} 
and Moroccan or Tunisian growth rates. This suggests that the correlations of $g_{t}^{M O R, N A}$ and $g_{t}^{T U N, N A}$ with growth in their European partners are not hiding the effect of a global cycle. ${ }^{8}$

\section{ESTIMATING THE SPILLOVERS}

\section{A. Identification Scheme}

We proceed with a VAR-based identification scheme in order to estimate the impact of an innovation in EU growth on Morocco and Tunisia nonagricultural GDP growth. More specifically, for country $\mathrm{j}$, the variables included in the baseline VAR are:

$$
Z_{t}=\left[g_{t}^{E U}(j), g_{t}^{j, N A}\right]^{\prime}
$$

The reduced-form VAR is:

$$
Z_{t}=c+\sum_{j=1}^{p} B_{j} Z_{t-j}+u_{t}, E\left(u_{t} u_{t}{ }^{\prime}\right)=V
$$

where $\mathrm{c}$ is a constant and $Z_{t}$ is the matrix with variables. The reduced-form residuals $u_{t}$ are mapped into the structural shocks $\varepsilon_{t}$ by the structural matrix $A_{o}$ :

$$
\varepsilon_{t}=A_{0} u_{t} \text {. }
$$

We use the inverse of the Choleski factor of the variance-covariance matrix $V$ to identify structural shocks that are orthogonal to each other, $E\left[\varepsilon_{t} \varepsilon_{t}^{\prime}\right]=I$, where $I$ is the identity matrix. This corresponds to the assumption that on impact structural shocks in Tunisia have a zero effect on shocks in European partner countries. It is important to note that changing the ordering of the variables in $Z$ did not change our results.

\section{B. Responses to External Growth Shock}

For each country we use the longest available quarterly data for the VAR estimation. For Morocco, the sample covers the period 1990Q1 to 2009Q4, whereas for Tunisia the dataset is from 2000Q1 to 2009Q4. ${ }^{9}$ Despite covering a relatively short time span, these datasets allow us to capture the recent period of high growth with important structural changes followed by the adverse shock of 2008-09. We include two lags in the estimated VARs. According to the Schwarz information criteria, this is the optimal lag length for both Morocco and Tunisia.

\footnotetext{
${ }^{8}$ T-tests also fail to reject the hypothesis that correlations of Moroccan or Tunisian GDP growth rates with US real GDP growth are significantly different from zero.

${ }^{9}$ Simulations run for Morocco on the 2000Q1-2009Q4 time interval lead to very similar results to the ones presented in this paper.
} 
Figure 5 shows impulse response function (IRFs) of growth in Morocco and Tunisia to a one standard deviation shock in the growth of GDP in the economic partners. The graph also includes standard error bands encompassing the 95 percent confidence interval. The impulse response of both Morocco and Tunisia GDP growth to EU GDP growth is significantly different from zero in the first four quarters. A variation of one percentage point in EU GDP growth produces a similar peak response in Morocco (0.59 in the second quarter) compared to Tunisia (0.62 in the third quarter) but generates a more abrupt and short lived response for Morocco, while the response is more persistent in the case of Tunisia.

As a robustness check, we also reversed the order of the growth rates in the VAR, and found similar results. As expected, in all the SVARs, growth shocks in Morocco and Tunisia generate nonsignificant responses on growth in the EU partner countries. ${ }^{10}$

Figure 5. Response of Domestic Growth to an External Growth Shock
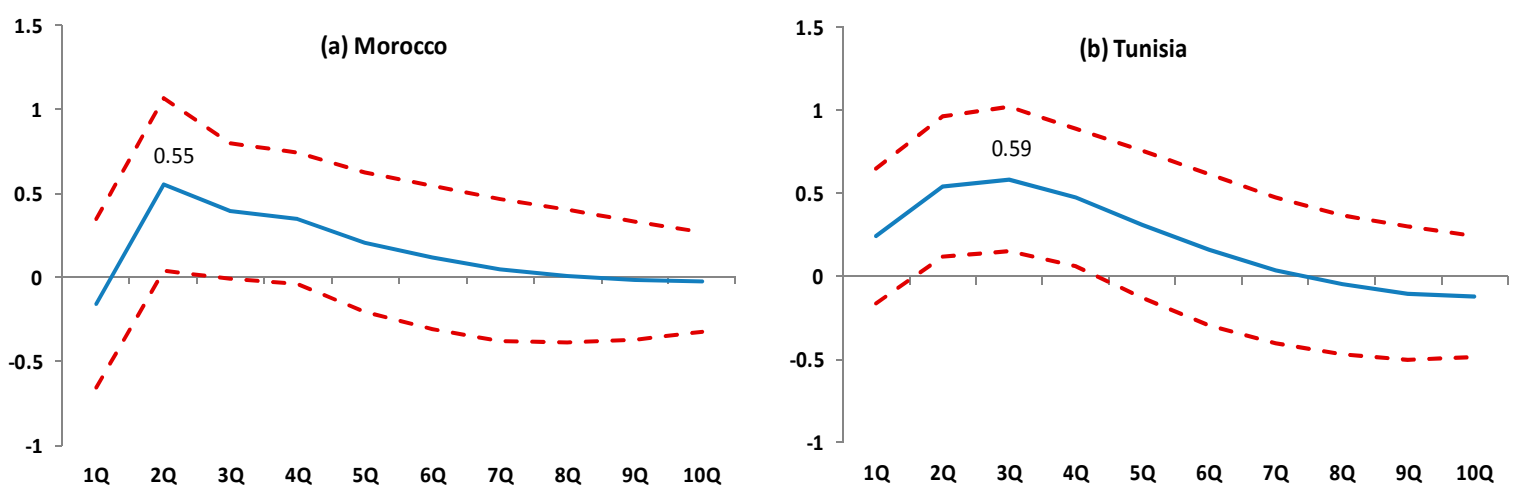

Source: IMF staff estimates.

The variance decompositions reported in Table 3 show how much of the forecast error variance of a country's GDP growth can be explained by the structural shocks to GDP growth in EU partner countries. The share explained by $g_{t}^{E U}(M O R)$ and $g_{t}^{E U}(T U N)$ increases at longer horizons. At a 10-quarter forecast horizon, shocks to $g_{t}^{E U}(M O R)$ explain 11 percent of Morocco's GDP growth whereas shocks to $g_{t}^{E U}(T U N)$ explain 38 percent of Tunisia's GDP growth.

\footnotetext{
${ }^{10}$ Furthermore, forecast error variance decompositions show that the shocks in Morocco and Tunisia do not explain the shocks in EU partner countries.
} 
Table 3. Forecast Error Variance Decompositions

\begin{tabular}{c|cc}
\multicolumn{3}{c}{ Explained by $g_{t}^{E U}(\cdot)($ in \%) } \\
\hline Quarter & Morocco & Tunisia \\
\hline 1 & 0.49 & 3.78 \\
2 & 6.01 & 17.20 \\
3 & 8.12 & 28.94 \\
4 & 9.91 & 34.55 \\
5 & 10.51 & 36.71 \\
6 & 10.71 & 37.28 \\
7 & 10.74 & 37.31 \\
8 & 10.74 & 37.36 \\
9 & 10.74 & 37.58 \\
10 & 10.75 & 37.90 \\
\hline
\end{tabular}

Source: IMF staff estimates.

\section{Alternative Identification of Shocks}

We analyze the robustness of the earlier results by considering a long-run identification scheme for the structural shocks in EU partner countries. Specifically, rather than identifying the structural shock in EU partner countries by imposing a zero response on impact, we identify this shock by assuming that growth in Morocco or Tunisia has no long-run impact on GDP in partner countries. This assumption can be motivated by the size of Morocco or Tunisia's economy compared to that of partner countries. Following Blanchard and Quah (1989), the variables included in the baseline VAR are ordered as before:

$$
Z_{t}=\left[g_{t}^{E U}(j), g_{t}^{j, N A}\right]^{\prime} .
$$

The long-run effects of the structural shocks are given by:

$$
Z_{\infty}=\Theta \varepsilon_{t} .
$$

The identification assumption for the long-run restriction is then:

$$
\Theta(1,:)=[\Theta(1,1) \quad 0]
$$

Figure 6 shows that the IRFs to structural shocks in EU partner countries identified using this long-run restriction scheme resemble the shocks identified in the short-run identification scheme. We also added IRFs to a one standard deviation shock of the reduced-form residual, so without making any identifying restriction on the correlation matrix of the residuals $u_{t}$. The figure suggests that both the short-run and long-run restrictions do not impose big transformations. 
Figure 6. Short-Run versus Long-Run Restrictions
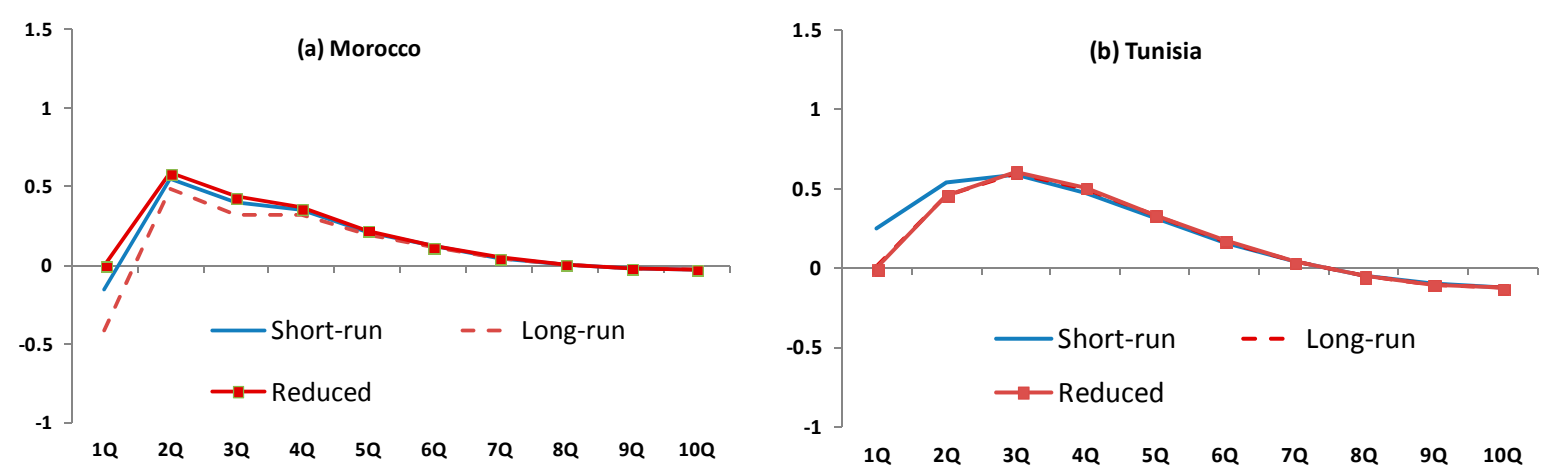

Source: IMF staff estimates.

\section{Decomposing the Spillovers by Transmission ChanNels}

To get a sense of the relative importance of different transmission channels we follow the approach proposed in Bayoumi and Swiston (2009). The SVARs are augmented one at a time with data on trade, tourism and remittances as exogenous variables. The potential contribution $c_{k}$ of a particular channel $k$ is then calculated as:

$$
c_{k}=r-r_{k} .
$$

The contribution $c_{k}$ is the difference between the responses of growth in Morocco or Tunisia to growth in partner countries $(r)$ minus the response of growth when the spillover is included as an exogenous variable $\left(r_{k}\right)$. The idea is that adding the exogenous variable to the VAR leaves in $r_{k}$ the part of the response that is not associated with the transmission channel $k$ (Figure 7).

Figure 7. Bayoumi and Swiston Approach

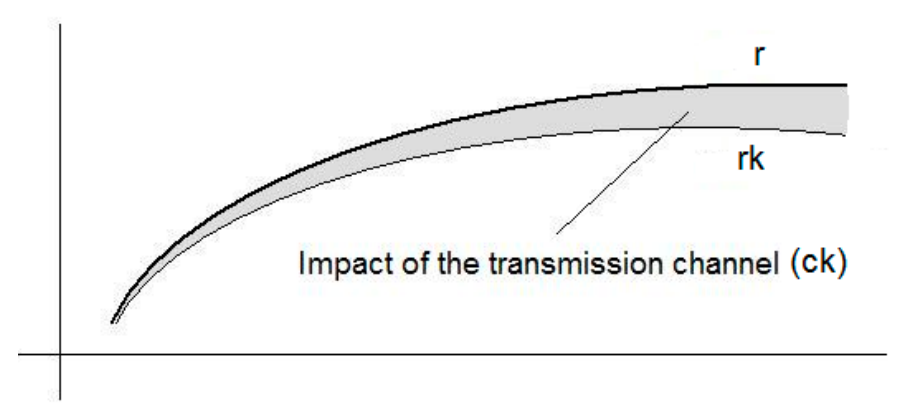

Source: IMF staff estimates.

This approach does not exclude the existence of other relevant transmission channels and does not account for the collinearity between the different channels. This also implies that the sources of spillovers $c_{k}$ are not necessarily required to sum up to the impulse response $r$. As such, we 
prefer to think of this technique as a gauge providing an indication of the relative importance of the major channels and not as a precise break-down of the impulse response. ${ }^{11}$

Figure 8. Cumulative Responses to Growth Innovation in Partner Composite
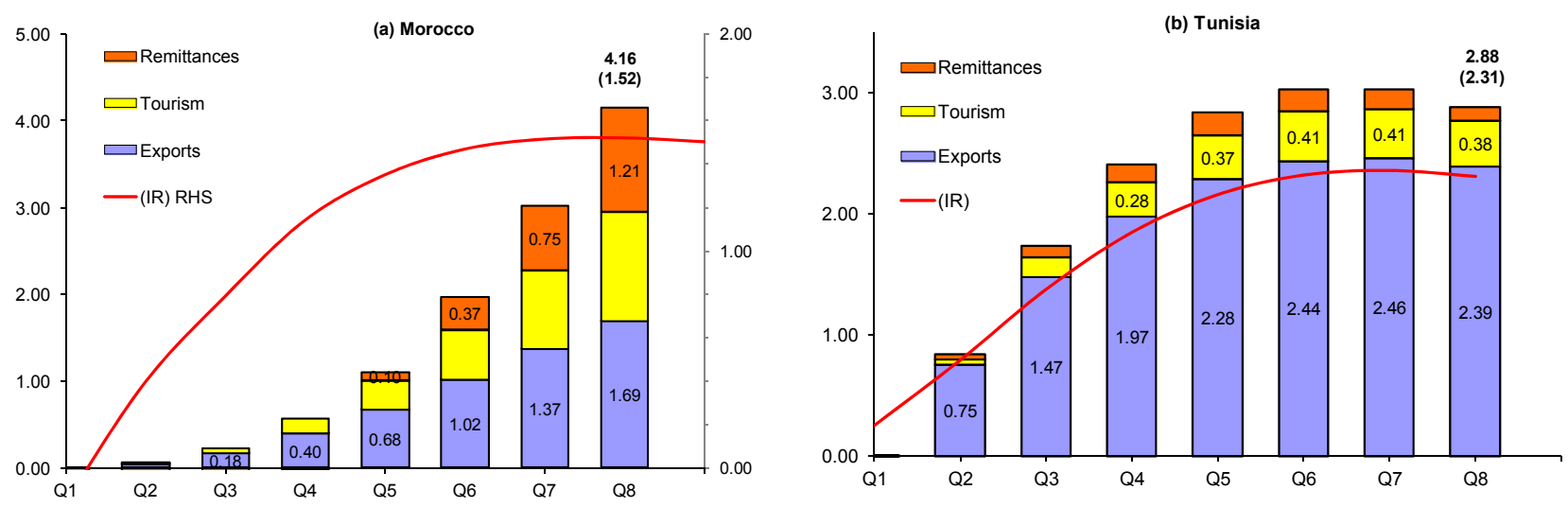

Source: IMF staff estimates.

Figure 8 shows the cumulative impact of the different contributions $c_{k}$ determined with this method for Morocco and Tunisia, where the structural shocks are identified as in Section III.A. We also include the cumulative impulse response function of the SVARs estimated in Section III.B. The analysis suggests that, in the case of Tunisia, exports, and to a much lesser extent tourism, are the major transmission channels. Remittances seem to play a very limited role at these frequencies. For Morocco, the results show that besides exports, which still play an important role, remittances and tourism are also major transmissions channels for spillovers. Cross-correlations between the three flows are significant in the case of Morocco.

These results are in line with the actual evolutions in exports, tourism and remittances observed during the recent slowdown in Europe (Figure 9). In Morocco all the three variables strongly responded to the sharp drop in EU GDP. ${ }^{12}$ In Tunisia, on the other hand, exports were the most affected. Tourism receipts in Tunisia were less affected, while remittances showed a remarkably strong resilience.

\footnotetext{
${ }^{11}$ For more details on this approach, see Bayoumi and Swiston (2009).

${ }^{12}$ Total export performance in Morocco is also influenced by sharp fluctuations in international prices and volumes of phosphate exports. The share of phosphate in total exports was 8 percent in 2007, 14 percent in 2008, and 7 percent in 2009. Quantities decreased 16 percent in 2008 and 50 percent in 2009, whereas prices more than tripled in 2008 and fell 41 percent in 2009.
} 
Figure 9. Reactions to the Recent Slowdown in Europe

(3 month moving average y-o-y growth rates of variables in local currency, in percent)
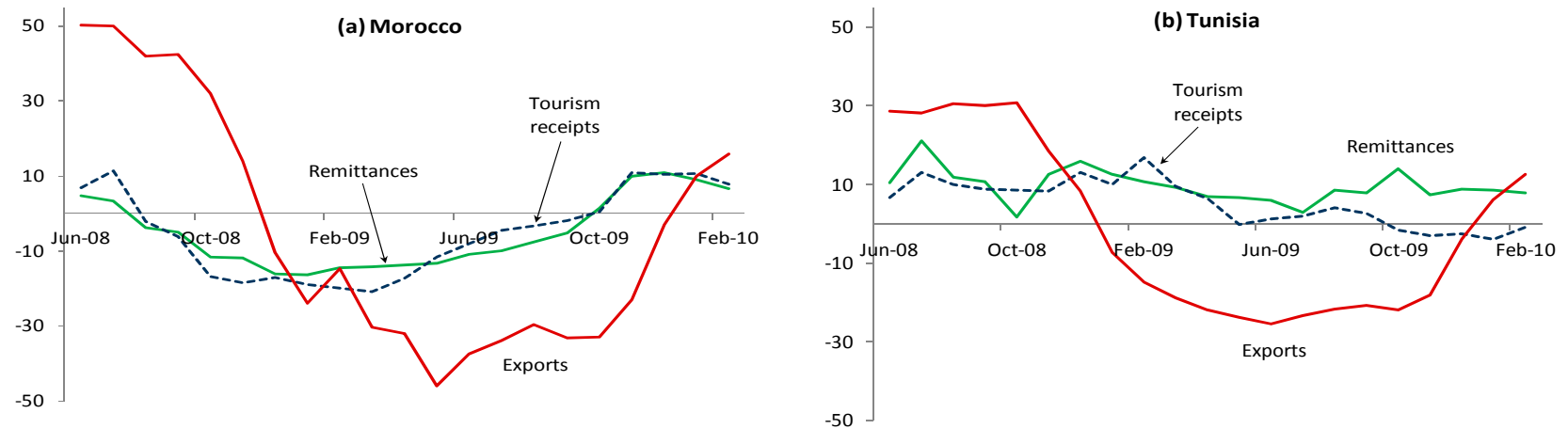

Source: Country's authorities; and IMF staff estimates.

\section{Sectoral Analysis}

In this section we test the robustness of the previous results by examining the response of growth in different sectors to growth shocks in EU partner countries. To this aim, we re-run the SVAR and replace the nonagricultural GDP growth rates for Tunisia and Morocco with the GDP growth rates $g_{t}^{j, S E C T O R}$ in particular sectors. As in Section III B, the impulse response measures the reaction of these sectors' value added growth rate to the country-specific EU GDP composite. For country $\mathrm{j}$, the variables included in the VAR are then:

$$
Z_{t}=\left[g_{t}^{j, S E C T O R}, g_{t}^{E U}(j)\right]^{\prime}
$$

In line with the results presented in Section IV, Figure 10 shows that in Morocco service-related sectors, which are more significantly influenced by tourism and transfers, appear to be more sensitive to the European cycle. Sectors such as manufacturing, construction, mining and energy do not seem to be significantly influenced. By contrast, in Tunisia export-oriented sectors, such as manufacturing and energy, are the most responsive. Agriculture, mining and other services show weak reactions to the variations in EU GDP.

Figure 10. Cumulative Response of Sector Growth to an External Growth Shock
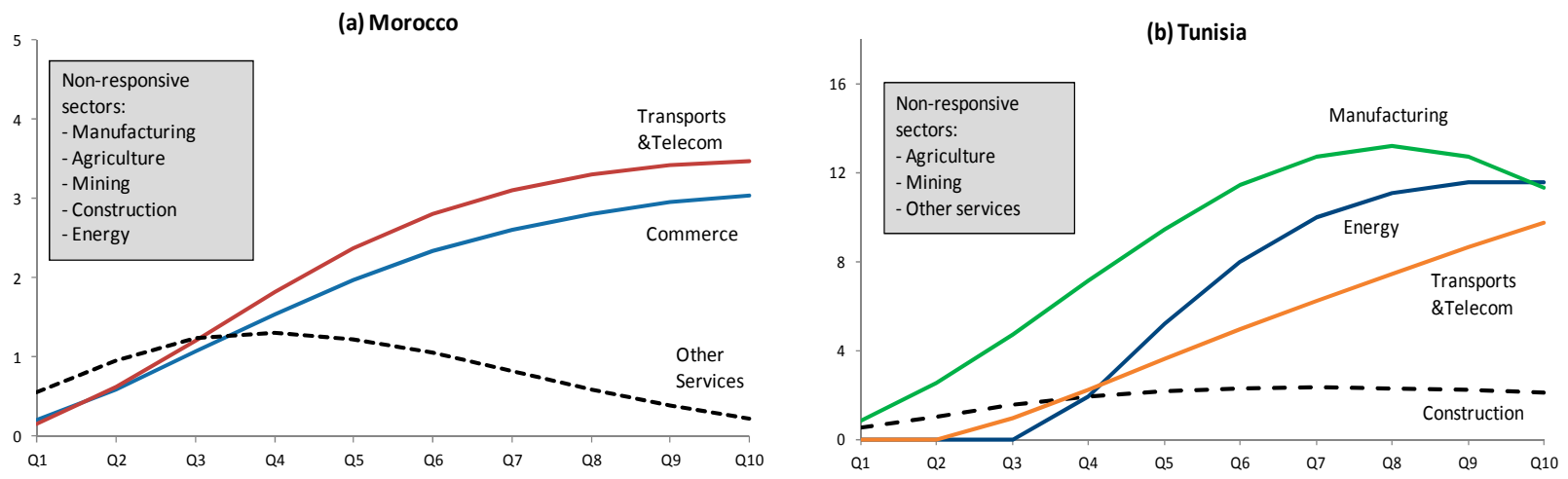

Source: IMF staff estimates. 


\section{Policy Implications}

The econometric analysis demonstrates that, for both Tunisia and Morocco's economies, the European Union plays a key role. Our analysis confirms the robustness of this connection and examines relative importance of its different transmission channels. While these close ties with the European Union have been a central factor contributing to the process of opening up the two economies and improving their competitiveness, they might also represent a challenge for the future.

Real output dropped by more than 4 percent in the Euro Area in 2009. Moreover, current forecasts are that the rebound in the EU area will be modest and slow. Growth in both domestic demand and real GDP will stay below their pre-crisis levels in the years to come (Figure 11). Recent concerns about sovereign debt and the sustainability of public finances in Southern European countries add further downside risks to this outlook.

Figure 11. Euro Area-Real GDP and Real Imports Growth (In percent)
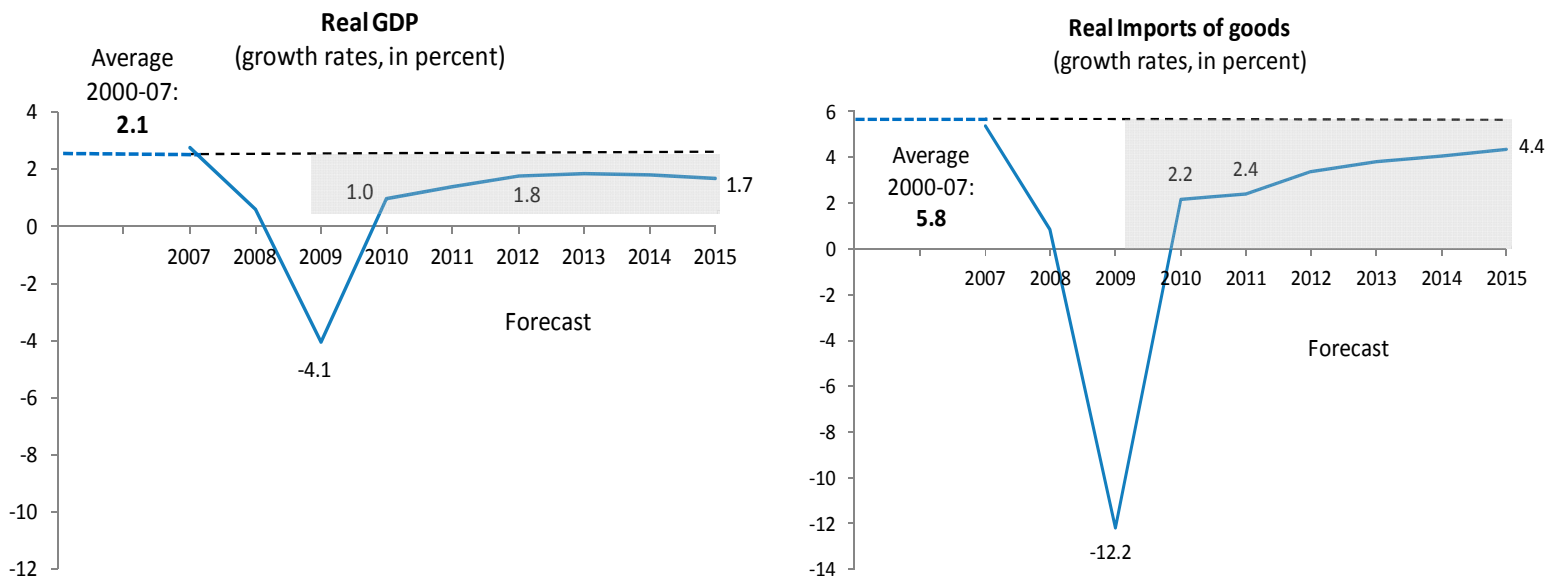

Source: IMF, World Economic Outlook (April 2010) and World Economic Outlook Update (July 2010).

Not only will real GDP growth in Europe be lower, but the engines of growth in Europe are expected to change, with less contribution coming from the domestic demand. As a result, growth in European imports - which represents the main source of external demand for Morocco and Tunisia - is projected to be less than half compared to the pre-crisis period in 2010 and 2011 (Figure 11).

It is noteworthy that following the association agreements the market shares of Morocco and Tunisia in EU merchandise imports have not increased since 1999. Table 4 shows that these market shares have remained fairly stable or slightly decreased over the past decade. Several factors can explain this evolution, such as the increased liberalization of world trade under the WTO agreements and the fierce competition from fast-growing exporters such as China and Eastern Europe. Against this backdrop, maintaining market share is more than honorable. 
Table 4: Morocco and Tunisia Shares in EU Imports

(In percent)

\begin{tabular}{lcccccccccc}
\hline EU (27 countries) & 1999 & 2000 & 2001 & 2002 & 2003 & 2004 & 2005 & 2006 & 2007 & 2008 \\
\hline Morocco & 0.8 & 0.6 & 0.7 & 0.7 & 0.7 & 0.6 & 0.8 & 0.5 & 0.6 & 0.5 \\
Tunisia & 0.7 & 0.6 & 0.6 & 0.7 & 0.7 & 0.7 & 0.6 & 0.6 & 0.6 & 0.6 \\
\hline
\end{tabular}

Source : Eurostat. Data excludes intra-EU trade flows.

Morocco and Tunisia have weathered the recent slowdown in Europe well, due to relatively insulated financial systems, an exceptional agricultural production and strong domestic demand in 2009. In fact, growth accounting exercises suggests that domestic demand has become a more dynamic source of growth in both countries from 2008 onwards. However, increasing competitiveness and a further diversification of trade flows represent key challenges to sustain growth in the future.

Figure 12 shows the shares of the EU and Maghreb in exports, imports and the destinationspecific cover ratio (exports to over imports from a region). The figure shows that trade with other Maghreb countries is marginal for both Morocco and Tunisia, and represents an unexploited potential, especially in the context of the more subdued growth projections for the European market.

Figure 12. EU and UMA Shares in Imports, Exports and Cover Ratio, 2008 (In percent)
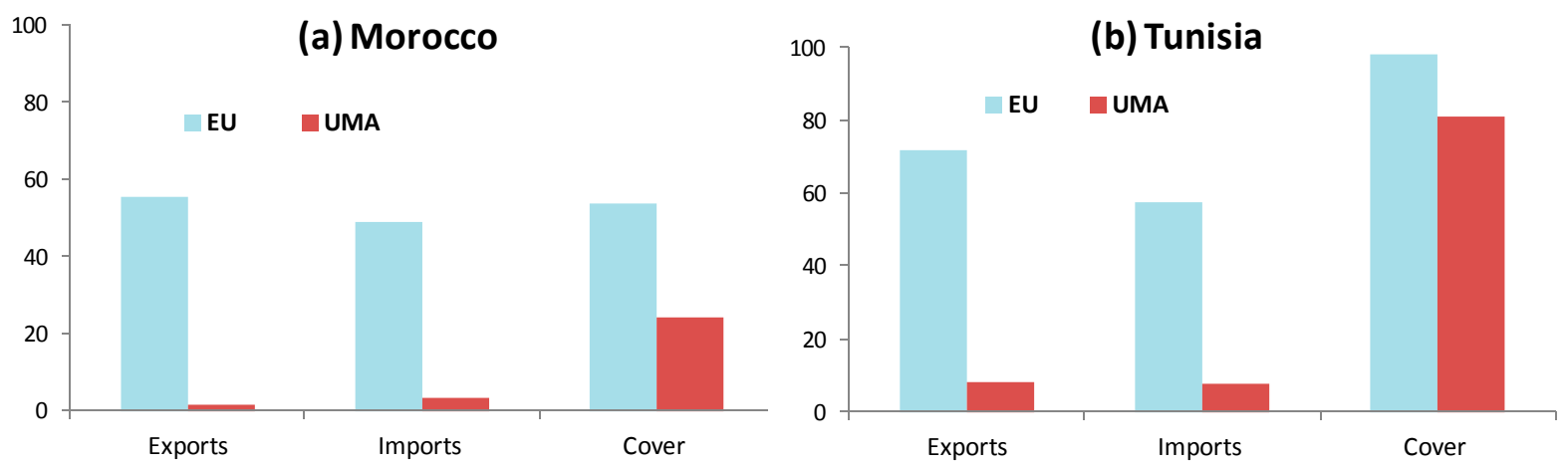

UMA = Union du Maghreb Arabe (Algeria, Libya, Mauritania, Morocco, Tunisia).

Source: Country's authorities and IMF staff estimates.

\section{CONCLUSION}

We have shown that for both Morocco and Tunisia nonagricultural GDP growth rates are significantly influenced by the variations in GDP of their main European partners. However, the transmission channels appear to be different between the two countries. In the case of Tunisia, growth shocks are mainly transmitted through exports and, to a much lesser extent, tourism. Exports, tourism receipts and remittances play equally important roles in Morocco. These results are confirmed by the evolution of export, tourism, and remittances in the wake of the recent 
slowdown in Europe. A similar exercise at the sectoral level indicates that the sectors related to services are the most responsive to EU's GDP in Morocco, while in Tunisia the most responsive sectors are more export-oriented.

While our findings show a remarkable coherence, there are a number of limitations to keep in mind when interpreting these results. First, it should be emphasized that a VAR analysis is not a growth accounting exercise. It shows the sensitivity of the dependent variable to external shocks rather than the influence of different components on growth. Moreover, the results of the breakdown by transmission channel are only tentative. Other potentially important channels, such as FDI, imports and financial sector linkages, which have structural impacts on the economy in the long run, certainly warrant further study.

Our analysis confirms the important role played by the European Union for the Moroccan and Tunisian economies. We note, however, that this close tie might also represent a challenge for the future. For the two countries, enhancing competitiveness and diversifying trade flows is essential for sustaining future growth. 


\section{APPENDIX. Trade Weights from the Global Economic Environment (GEE)}

Global Economic Environment (GEE) data are group composites, based on weighted averages of selected World Economic Outlook (WEO) variables from the country databases. The trade weights are derived from the IMF's Direction of Trade (DOT) database. Every country has four sets of trade weights, i.e., the imports and exports weights for all countries as partners, and the imports and exports weights for only the advanced economies. The weights are calculated from the GEE reporting country's trade with partner which comprise 95 percent of the reporter's total exports or imports. The additional 5 percent partner countries of the reporter's trade data do not warrant any improvement in the overall trade weights. The GEE calculates a reporting country's series not from the reporting country's data but from the aggregated sum of the weighted percentage changes of its partners' data for a given WEO series.

\begin{tabular}{lr} 
Morocco & \\
\hline France & 36.36 \\
Spain & 33.42 \\
United Kingdom & 8.22 \\
Italy & 7.87 \\
Belgium & 5.33 \\
Germany & 5.20 \\
Netherlands & 3.60 \\
\hline Total & $\mathbf{1 0 0}$
\end{tabular}

\begin{tabular}{lr} 
Tunisia & \\
\hline France & 42.2 \\
Italy & 29.1 \\
Germany & 10.9 \\
Spain & 7.6 \\
Belgium & 3.7 \\
United Kingdom & 3.5 \\
Netherlands & 2.9 \\
\hline Total & $\mathbf{1 0 0}$
\end{tabular}

The above tables show the GEE weights used for calculating the country-specific composite EU growth rates $g_{t}^{E U}(\bullet)$. As we want to attribute weights to the GDP growth of the EU countries, the EU countries' weights have been normalized such that the sum is 100 . The country-specific composite GDP growth rate $g_{t}^{E U}(\bullet)$ can be expressed as follows, based on the weights $\alpha_{t}^{i}$ the EU countries take in Morocco's and Tunisia's exports of goods, respectively, and on these countries' growth rates $\mathrm{g}^{\mathrm{i}}$ :

$$
g_{t}^{E U}(\bullet)=\frac{\sum_{i=1}^{n}\left(g_{t}^{i} \alpha^{i}\right)}{\sum_{i=1}^{n} \alpha^{i}}
$$




\section{References}

Arezki, R., R. Cherif, and J. Piotrowski, 2009, “Tourism Specialization and Economic Development: Evidence from the UNESCO World Heritage List," IMF Working Paper 09/176 (Washington: International Monetary Fund).

Baxter, M., and M. Kouparitsas, 2005, "Determinants of Business Cycle Comovement: a Robust Analysis," Journal of Monetary Economics, Vol. 52(1), January, pp.113-57.

Bayoumi, T. and A. Swiston, 2009, "Foreign Entanglements; Estimating the Source and Size of Spillovers Across Industrial Countries," IMF Staff Papers, Vol. 56(2), pp. 353-83.

Blanchard, O. and D. Quah (1989), “The Dynamic Effects of Aggregate Demand and Supply Disturbances," American Economic Review, Vol. 79(4), pp. 655-73.

Canova, F., and H. Dellas, 1993, "Trade Interdependence and the International Business Cycle," Journal of International Economics, Vol. 34 (February), pp. 23-47.

Gapen M. T., A. and others, 2009, “Do Workers' Remittances Promote Economic Growth?” IMF Working Paper 09/153 (Washington: International Monetary Fund).

Imbs, Jean (2004), "Trade, Finance, Specialization, and Synchronization," Review of Economics and Statistics, Vol. 863, pp.723-34.

Kose, M.A., C. Otrok, and C.H. Whiteman, 2003, "International Business Cycles: World, Region, and Country-specific Factors," American Economic Review, Vol.93 (4), pp. 121639.

Toujas-Bernaté, J., B. Loko, and D. Simard, 2009, "Investigating Growth Spillovers from Europe," Tunisia Selected Issues Paper, IMF Country Report No. 10/109. 